\title{
Criteria for High Quality Biology Teaching: An Analysis
}

\author{
Guntay Tasci ${ }^{\mathrm{a}}$ \\ Erzincan University
}

\begin{abstract}
This study aims to analyze the process under which biology lessons are taught in terms of teaching quality criteria (TQC). Teaching quality is defined as the properties of efficient teaching and is considered to be the criteria used to measure teaching quality both in general and specific to a field. The data were collected through classroom observations in this study, whose research was collected using a qualitative method. The research contained 21 classroom observations from 5 different biology teachers in 5 different high schools in Ankara, Turkey. The classes involved differing topics taught in $9^{\text {th }}, 10^{\text {th }}, 11^{\text {th }}$, and $12^{\text {th }}$ grades. The data first underwent the structured content analysis using the MAXqda program. The encoding numbers for the codes in the data were transferred into the MS Excel program and were used to make quantitative analyses. The classrooms observed were grouped in terms of teaching quality criteria using cluster analysis using the SPSS 19 program. Similar groups, on the other hand, were evaluated according to cognitive structuring and teaching quality. As a result, avoiding the use of various methods, using effective teaching materials, and employing strict classroom management in biology teaching with the study group heavily increased the number of concepts communicated whereas problems in classroom management and classroom atmosphere reduced the concepts, thus influencing cognitive structure in a negative way. Finally, asking deepening questions and evaluative feedback affected cognitive structure in a positive way.
\end{abstract}

Keywords: Biology teaching $\bullet$ Teaching quality $\bullet$ Classroom observation $\bullet$ Cognitive structuring

\section{a Correspondence}

Assist. Prof. Guntay Tasci (PhD), Primary School Teaching Department, Faculty of Education, Erzincan University, Erzincan 24000 Turkey

Research areas: Multi-media applications in biology teaching; Self-regulated learning strategies; Cognitive structure and research into the quality of teaching Email: gtasciderzincan.edu.tr 
Helmke (2009) stresses that the detailed and temporal sequence of educational and teaching activities whose topic domain is restricted in educational institutions and which are didactically planned should be understood from the concept of teaching. Setting out from this definition, the concept of teaching quality is used for the sum of the teaching properties effective according to the previously set normative targets in a larger sense (Clausen, Reusser, \& Klieme, 2003; Einsiedler, 2002). Research studies in this context make attempts at exhibiting the criteria for good teaching. The teaching models based on behavioral and cognitive learning approaches displayed by such educational researchers as Caroll, Ausebel, and Bloom are considered as the pioneers in this field (Hasselhom \& Gold, 2006; Lipowski, 2009). So as to research teaching quality, the concepts of effective teaching and a good teacher were discussed, and research studies established different research traditions over time. They are reported as the paradigm of teacher personality, the processproduct-paradigm, and expertise paradigm (Doyle, 1977). Several isolated variables are identified for teaching quality in independent research studies performed within the scope of those paradigms. Those variables are brought together on upper dimensions via meta-analysis studies, and attempts are made to determine and describe the criteria for quality teaching. The variables determined in those studies in relation to teaching quality are summarized in Table 1 based on Neuhaus (2007). The principles put forward initially by those attempts are considered to be independent of the field or to be teaching quality criteria.

Dimensions determined accordingly mostly contain classroom management and related variables. Examining Tracers' behavioral patterns causing an increase in teachers' maximum performance Kouins (1976) identifies effective classroom management principles based on the paradigm of teacher personality. Classroom management, which is studied in the most detail and which is considered to be the central issue of teaching research, is considered from the following three perspectives: (1) imposing rules preventing time waste and disturbance, (2) time management for successful teaching, and (3) coping with disturbances effectively. Structuring the teaching process is yet another dimension considered in even different ways. Firstly, one way to structure a lesson is to segment the course into specific portable stages and sections and to divide the course content into pieces. On the other hand, teachers' directing students' attention to key points on the basis of cognitive psychological structuring may be regarded as presenting mental ties so as to build connections between old and new information. Managing the cognitive processes of learners in the teaching process in such a way is an important step in the formation of their cognitive structure. In this case, presenting concepts forming the lesson's content with teaching methods and techniques both in general and specific to the subject at hand seem to be of key importance (Eisiedler \& Hardy, 2010; Lipowski, 2009). The results of national and international performance comparison studies add a new perspective to traditions. Thus, it is emphasized that the criteria used to ascertain teaching quality in studies be considered along with field specific combinations as well as their complex interactions with variables specific to the field (Ditton, 2002; Helmke, 2010).

Normatively determined teaching properties of the biology are available within the didactics of biology (Berck, 2005; Eschenhagen, Kattmann, \& Rodi, 2000; Killermann, Hiering, \& Starosta, 2009; Köhler, 2004). According to the literature, teaching biology in accordance with scientific processes and skills is the main objective. Neuhaus (2007) suggests a theoretical

\begin{tabular}{|c|c|c|c|c|}
\hline Author & Fraser et al. (1987) & Brophy et al. (1999) & Clausen et al. (2003) & Helmke (2004) \\
\hline $\begin{array}{l}\text { Quality } \\
\text { Criteria }\end{array}$ & $\begin{array}{l}\text { - Reinforcement } \\
\text { - } \text { Heedback } \\
\text { - } \text { Cooperative } \\
\text { learning } \\
\text { - Meaningful } \\
\text { learning } \\
\text { - Focusing on } \\
\text { important content } \\
\text { - Types of teachers' } \\
\text { questions } \\
\text { - Having } \\
\text { experiments done }\end{array}$ & $\begin{array}{l}\text { - Supportive classroom } \\
\text { climate } \\
\text { - Amount of time for } \\
\text { learning } \\
\text { - Coherent content } \\
\text { - Goal setting and } \\
\text { orientation } \\
\text { - Thoughtful discourse } \\
\text { - Strategy teaching } \\
\text { - Scaffolding students' task } \\
\text { engagement }\end{array}$ & $\begin{array}{l}\text { - } \text { Classroom } \\
\text { management } \\
\text { - Goal setting and } \\
\text { orientation } \\
\text { - Cognition } \\
\text { activating } \\
\text { - Structuring the } \\
\text { content and its } \\
\text { clarity }\end{array}$ & $\begin{array}{l}\text { - Effective classroom } \\
\text { management } \\
\text { - Atmosphere encouraging } \\
\text { learning } \\
\text { - Motivating } \\
\text { - Clear presentation } \\
\text { - Directing teaching towards } \\
\text { efficacy } \\
\text { - Encouraging self-regulated } \\
\text { learning } \\
\text { - Establishing learning } \\
\text { - } \text { orientations } \\
\text { - Deariety of methods }\end{array}$ \\
\hline
\end{tabular}


framework in relation to adapting the general teaching quality criteria into the teaching of biology. Furthermore, the criteria for biology teaching were set by Wüsten, Schmelzing, Sandmann, and Neuhaus (2010) who stated that using real objects, models, terminology and ways specific to biology, structuring the content, and directing activities toward real life should act as quality criteria for biology education. The importance of concepts and teaching them in networks, the fit of the cognitive levels of teachers' questions and students' responses, and the quality of in-class dialogues constituting teacher-student interactions are among the important variables to have been researched in the context of biology teaching. While data are collected through video recordings during classroom observations, qualitative research methods are used in such research (Hugeneri Pauli, Reusser, Lipowsky, Rakoczy, \& Klieme, 2009; Pavlina, Zorica, \& Pongrac, 2011; Shadreck \& Isaac, 2012; Wadouh, 2007; Wüsten, Schmelzing, Sandmann, \& Neuhaus, 2010).

It is clear that the studies conducted in relation to biology education in Turkey are centered around teacher training, the professional development of teachers, evaluation of curriculum, and the qualities of teachers. Problems related to teaching, relevant recommendations, and views are collected in those studies through reviews made either nationwide or by individual provinces in Turkey. It is reported in those studies that biology teachers are inadequate in terms of biology practices in secondary education and that the inadequacies stem from insufficiencies in pre-service training. It is also reported by high school students that the problems of biology teaching revolve around physical insufficiencies in general and around application insufficiencies in their biology classes (Kaya \& Gürbüz, 2002; Öztaş \& Özay, 2004). In their study conducted on the basis of video analyses, Koç, Peker, and Osmanoğlu (2009) define the pieces of teachers' discourse, which they group into three categories: explanatory, confirmative, and informative, explaining the effects of each discourse. Doğan (2006), on the other hand, analyses primary school mathematics classes in terms of lesson pattern and teaching techniques via lesson observations. Gürbüz and Sülün (2004) emphasize that qualified prospective biology teachers should be trained and should gain the scientific process skills in order to teach biology at a high level of quality. In their study with biology teachers in Turkey, Altunoğlu and Atav (2005) discovered two factors found to inhibit students from learning biology. The first of these factors was students' arriving at the higher stage of education from primary school with insufficient knowledge and the second was students' negative attitudes toward their biology course. In a study by Öztürk Akar (2005) it was concluded that there are differences between schools in terms of implementing biology curriculum and that such traditional teaching methods and techniques employed by biology teachers as asking questions and direct instruction are used. The same study also found that lab applications are kept at minimum levels. In a number of other studies performed in which the methods and techniques used by biology teachers are described, it is highlighted that such methods and techniques should be modernized (Atıc1 \& Bora, 2004; Temelli \& Kurt, 2011). The study conducted by Çimer (2004) investigated views for effective biology teaching through surveys and interviews with both biology teachers and high school biology students. Similarly, this study also reported the use of teacher-centered biology teaching which makes little use of experiments and suggests that measures be taken both for teacher training and teachers' professional development. It was found during the literature review that while teaching quality had been researched on the basis of expertise using questionnaires to obtain views, the effect of class length on teaching quality criteria had been scarcely researched. Aydin and Boz (2012), in their literature compilation, analyzed teachers' and prospective teachers' knowledge based on different components in science education within Turkey.

Helmke (2002) claims that teaching quality should be evaluated through a perspective specific to the subject by taking into consideration the nature of the subject, the structure of the curricula, and the methods of study. For these purposes, the discipline of teaching itself must be made into the object of research (Fischer, Borowski, Kauertz, \& Neumann, 2010). In their research, Öztürk and Demircioğlu (2002) found that the in-class behaviors of biology teachers as biology curriculum practitioners should be researched. Apart from studies concerning teachers, students, and administrators' perceptions of teachers' efficacy, students' learning outcomes, or lesson quality, observing the variables related to teaching quality in real processes is an aspect gaining importance in research on biology teaching quality (Rixius \& Neuhaus, 2010; Wüsten et al., 2010; Wüsten, Schmelzing, Sandmann, \& Neuhaus, 2008). As was also discussed in the literature, biology teaching quality should be analyzed according to variables and their interactions rather than simply according to isolated variables (Ditton, 2002; Rixius \& Neuhaus, 2010). In relation to this, O' Sullivan (2006) considers lesson 
observations important in their ability to comprehend the reality of a lesson as it unfolds. The researcher points out that measuring students' achievement alone cannot fully reflect teaching quality and recommends using such classroom-based methods as lesson observations and student interviews to achieve this. In this framework, among the necessities of biology teaching are analyzing biology teaching in terms of quality criteria, describing the transfer of biological knowledge and which variables influence the transfer and the structuring of biological knowledge. This is a pioneering study for more comprehensive lesson observations to be made in the future in relation to biology teaching. This study is important for two reasons; the first being that it reviews the literature and research methods, thus forming the codes framework for qualitative data analyses and the second reason being that it familiarizes prospective research studies with the field.

This study aims both to describe biology classes in terms of teaching quality variables and to analyze the states of cognitive structuring. Therefore, this study focuses on three main elements (1) teachers' and students' behaviors, which constitute the process of biology teaching, (2) the lesson pattern, and (3) the cognitive flow of the lesson from the perspective of TQC for the lesson process as it is composed of student-teacher interactions. The properties of those lesson processes which share similar TQC variables are examined in groups and the structuring properties of these groups are compared in this study.

\section{Research Questions}

1. Do different biology lessons share similar variables rating teaching quality?

2. How is cognitive structuring in biology teaching conducted in similar groups according to teaching quality variables?

\section{Method}

Research for this study was performed under a holistic multiple case design. Accordingly, the data were collected through lesson observations in which the researcher monitored teaching in its natural flow in the classroom-the natural environment of teaching-according to a predetermined framework by the observers who do not interfere with the process is compatible with structured field study (Ylldırım \& Şimşek, 2006).

\section{Study Group}

Different grades, topics, teachers, and grade levels were reached by using maximum variation sampling (Ylldırım \& Şimşek, 2006). This sampling method researches similarities and differences having different variables. Thus, the research involves 21 lesson observations made in 5 different high schools in Ankara, Turkey. The school types, grade levels, teachers' experience, gender, and the topic of the classroom observed are shown in Table 2.

According to Table 2, five teachers (one male and four female) with 11-14 year teaching experience were observed in 7 different classrooms for a period of 2-7 class hours. The lessons contained the presentation, revision, and test questions of $9^{\text {th }}, 10^{\text {th }}, 11^{\text {th }}$, and $12^{\text {th }}$ grade biology topics. Each observation lasted for 40 minutes (a class hour). The codes shown in Table 2 were created for each class and teacher, and the observations and analyses were conducted with those codes. Pre-studies were not done to form this sample of the research. Instead, the study was conducted with the biology teachers who had been reached randomly and who had permitted data collection. Since the research did not aim to perform analyses on the basis of school types or teachers' experience, adding the observations to increase variety was considered sufficient. The number of observations in the study group was decided upon by ensuring that the variety was sufficient for qualitative analyses and that it was three times as many as the number of variables necessary for quantitative analyses (Bortz, 2005).

\section{Data Collection}

The research data were collected through lesson observations in accordance with a structured field study, as recommended by Yıldırım and Şimşek (2006). For our purposes, lesson observations were made in accordance with the framework suggested by Bellack (1972). The framework involves such procedures as the determination and classification of the behaviors to be observed in the lesson, the formation of special observation framework, and the determination of behavioral units.

\section{Procedures}

The teaching process was observed by four fifth year biology teaching students during their School Experience course, and was recorded in writing. The data collection process lasted for 10 weeks for each of the two sequential semesters. While 30 lessons were 


\begin{tabular}{|c|c|c|c|c|c|c|}
\hline $\begin{array}{c}\text { The classroom code } \\
\text { observed }\end{array}$ & $\begin{array}{l}\text { School type } \\
\text { and code }\end{array}$ & Classroom & Gender & $\begin{array}{c}\text { Experience } \\
\text { (years) }\end{array}$ & $\begin{array}{c}\text { Teacher } \\
\text { code }\end{array}$ & Topic \\
\hline DG1 & High school-5 & $11 \mathrm{E}$ & Female & 13 & 1 & Digestive System \\
\hline DG4 & High school-5 & $11 \mathrm{E}$ & Female & 13 & 1 & $\begin{array}{l}\text { Circulatory } \\
\text { System }\end{array}$ \\
\hline DS5 & $\begin{array}{l}\text { Anatolian high } \\
\text { school -4 }\end{array}$ & $10 \mathrm{C}$ & Female & 14 & 2 & Ecological Units \\
\hline DG2 & High school-5 & $11 \mathrm{E}$ & Female & 13 & 1 & $\begin{array}{l}\text { Digestive System } \\
\text { (repeated) }\end{array}$ \\
\hline DG3 & High school-5 & $11 \mathrm{E}$ & Female & 13 & 1 & $\begin{array}{l}\text { Digestive System } \\
\text { (repeated) }\end{array}$ \\
\hline DS1 & $\begin{array}{l}\text { Anatolian high } \\
\text { school-4 }\end{array}$ & $11 \mathrm{C}$ & Female & 14 & 2 & $\begin{array}{l}\text { Organs Helping } \\
\text { Digestion }\end{array}$ \\
\hline DS2 & $\begin{array}{l}\text { Anatolian high } \\
\text { school-4 }\end{array}$ & $11 \mathrm{C}$ & Female & 14 & 2 & $\begin{array}{l}\text { Test (General } \\
\text { revision) }\end{array}$ \\
\hline DS3 & $\begin{array}{l}\text { Anatolian high } \\
\text { school -4 }\end{array}$ & $10 \mathrm{E}$ & Female & 14 & 2 & $\begin{array}{l}\text { Infectious } \\
\text { Diseases } \\
\end{array}$ \\
\hline DS6 & $\begin{array}{l}\text { Anatolian high } \\
\text { school-4 }\end{array}$ & $10 \mathrm{C}$ & Female & 14 & 2 & $\begin{array}{l}\text { Biotic- Abiotic } \\
\text { Factors }\end{array}$ \\
\hline DY10 & $\begin{array}{l}\text { Anatolia high } \\
\text { school-3 }\end{array}$ & $11 \mathrm{~A}$ & Female & 12 & 4 & $\begin{array}{l}\text { Cellular } \\
\text { Respiration } \\
\end{array}$ \\
\hline DY2 & $\begin{array}{l}\text { Anatolian high } \\
\text { school-1 }\end{array}$ & $9 \mathrm{E}$ & Female & 13 & 3 & $\begin{array}{l}\text { Respiration } \\
\text { (General } \\
\text { revision test) }\end{array}$ \\
\hline DS4 & $\begin{array}{l}\text { Anatolian high } \\
\text { school -4 }\end{array}$ & $10 \mathrm{C}$ & Female & 14 & 2 & $\begin{array}{l}\text { Ecology and } \\
\text { Ecosystem }\end{array}$ \\
\hline DY1 & $\begin{array}{l}\text { Anatolian high } \\
\text { school-1 }\end{array}$ & $9 \mathrm{E}$ & Female & 13 & 3 & $\begin{array}{l}\text { Mouth and } \\
\text { Dental Health }\end{array}$ \\
\hline DY3 & $\begin{array}{l}\text { Anatolian high } \\
\text { school-3 }\end{array}$ & $11 \mathrm{~A}$ & Female & 12 & 4 & Stem \\
\hline DY4 & $\begin{array}{l}\text { Anatolian high } \\
\text { school-1 }\end{array}$ & $9 \mathrm{E}$ & Female & 13 & 3 & Carbohydrates \\
\hline DY5 & $\begin{array}{l}\text { Anatolian high } \\
\text { school-2 }\end{array}$ & $10 \mathrm{E}$ & Male & 11 & 5 & $\begin{array}{l}\text { Aerobic } \\
\text { Respiration }\end{array}$ \\
\hline DY6 & $\begin{array}{l}\text { Anatolian high } \\
\text { school-2 }\end{array}$ & $10 \mathrm{E}$ & Male & 11 & 5 & Fermentation \\
\hline DY7 & $\begin{array}{l}\text { Anatolian high } \\
\text { school-2 }\end{array}$ & $12 \mathrm{E}$ & Male & 11 & 5 & $\begin{array}{l}\text { Respiratory } \\
\text { System }\end{array}$ \\
\hline DY8 & $\begin{array}{l}\text { Anatolian high } \\
\text { school-1 }\end{array}$ & $9 \mathrm{E}$ & Female & 13 & 3 & Cell \\
\hline DY9 & $\begin{array}{l}\text { Anatolian high } \\
\text { school-1 }\end{array}$ & $9 \mathrm{~B}$ & Female & 13 & 3 & Cell Organelles \\
\hline DY11 & $\begin{array}{l}\text { Anatolian high } \\
\text { school-1 }\end{array}$ & $9 \mathrm{~B}$ & Female & 13 & 3 & Air Pollution \\
\hline
\end{tabular}

observed in total, only 21 of them were analyzed. The data collection stages consisted of training the observing students, evaluating the experimental observations, and fulfilling the lesson observations.
Training the Observers: The training offered to the observers for data collection was performed in the following stages: (i) the students were informed of the nature of qualitative research and observations 
during 2 sessions of 2 hours each according to Yildırım and Şimşek (2006). (ii) The observers were introduced to the lesson process and its determined dimensions in accordance with the purpose of the research. Their awareness was raised so that they might be able to distinguish said dimensions in the dynamic flow of the lesson. The observation framework formed was introduced to the students in the training sessions. (iii) Because students would perform observations and record their observations in writing at the same time, a writing notation was given to the observers. According to the notation, abbreviations were determined, and the teacher's discourse would be represented by the letter "L," and the students' by the letter " $\mathrm{S}$," and the observer's descriptions would be within parentheses: "( )." Apart from that, the observers were also told to make note of the teachers' gender, the date and time of the observation, the school type, the classroom, and the point of teaching on the observation report. (iv) During the next stage, the observers were given instructions on the purpose of the observations, the observational framework, and the rules to be obeyed while performing observations. They were then given an informative form on data collection and on the principles of recording observation. The form was a summary of what had been instructed to them during the training sessions. Thus, care was taken so that the observers' notes on teachers' and students' oral statements during class and on the situations complementing them were collected in an easy to compare and systematic way.

Observational Framework: The headings of lesson observation, the physical structure of the classroom, classroom atmosphere, in-class interactions, learning-teaching process activities, and cognitive structure were explained. Classroom atmosphere was defined as the general make-up of the classroom in terms of students' and teacher's behaviors and the observers were asked to describe it. Descriptions contained such statements as the class is silent/ abuzz/ noisy/ complex/ listening/ active/ passive.' In-class interaction describes teacher-student, student-teacher, and studentstudent communication methods dominant during the lesson. The important aspect of these stages is that they do not involve biology content. Cognitive structure involves the behaviors that the teacher tries to instill in students while teaching the lesson's biology topic as well as the communication process in the meanwhile occurring through students' responses. In this process, it is demanded that the rules, the concepts, the meanings of the concepts, their relations, and ties in the biology topic-that is to say, the flow of the topic as a whole in the classroom-should be written.

Evaluation of the Experimental Observations: Regular weekly meetings were held with the observers during the data collection process. The observation reports written were read and analyzed together and were not considered as data until the reports had gained the desired format (9 class hours). The implicit, unclear conceptual expressions were a problem needing to be overcome in this process. The observing students were told that such statements as "the event of respiration is described in creatures" written in their observation reports did not represent the process and were told to report the knowledge transferred and the class atmosphere instead. Interventions were made to render the inconsistencies reported in terms of the process. For example:

10.20-10.30: (starting with respiration coefficient. The teacher said if the coefficient is equal to 1 , it is carbohydrate; if it is bigger than 1 , it is protein.)

In this reported observation, although the timing was stated as 10 minutes, it was asked whether the activity did indeed last that much. Thus, it was concluded that the observing students could not follow the teacher and that they could not write what had been instructed in the class in their reports. On the other hand, they were recommended to describe the cognitive structure in detail, to reflect the classroom atmosphere in the form of brief notes, and to use well-known abbreviations for the concepts in biology field knowledge. In this way, efforts were made to reach high quality observation reports describing the flow of the lessons clearly.

\section{Data Analysis}

The data were analyzed by using quantitative and qualitative analysis methods. First, a qualitative analysis of the observation notes was performed, then, based on the results, those groups similar in terms of teaching quality criteria (TQC) were formed through quantitative analysis.

Qualitative Analysis: The structured content analysis recommended by Mayring (2002) was employed for the qualitative analysis of the research data. Each lesson observation was used as the units of analysis, and differing units were used as the units of coding according to the properties of the categories. The coding system is shown in Table 3. 
Table 3

The Code System

\begin{tabular}{|c|c|c|}
\hline Categories & Upper codes & Codes \\
\hline \multirow{7}{*}{$\begin{array}{l}\text { Domain } \\
\text { specific } \\
\text { teaching } \\
\text { quality } \\
\text { (Teacher } \\
\text { activities) }\end{array}$} & \multirow{7}{*}{$\begin{array}{l}\text { Teaching } \\
\text { methods and } \\
\text { techniques }\end{array}$} & Using models \\
\hline & & Oral presentation \\
\hline & & $\begin{array}{l}\text { Technological } \\
\text { support }\end{array}$ \\
\hline & & $\begin{array}{l}\text { Using the } \\
\text { blackboard }\end{array}$ \\
\hline & & Analogy \\
\hline & & Feedback \\
\hline & & $\begin{array}{l}\text { Asking questions: } \\
\text { knowledge, } \\
\text { comprehension, } \\
\text { deepening }\end{array}$ \\
\hline \multirow{4}{*}{$\begin{array}{l}\text { General (In- } \\
\text { terdisciplin- } \\
\text { ary) teaching } \\
\text { quality } \\
\text { (Teacher } \\
\text { activities) }\end{array}$} & \multirow[t]{3}{*}{$\begin{array}{l}\text { Classroom } \\
\text { management }\end{array}$} & $\begin{array}{l}\text { Avoiding waste } \\
\text { of time }\end{array}$ \\
\hline & & $\begin{array}{l}\text { Structuring the } \\
\text { teaching hour }\end{array}$ \\
\hline & & $\begin{array}{l}\text { Atmosphere } \\
\text { encouraging } \\
\text { learning }\end{array}$ \\
\hline & $\begin{array}{l}\text { Classroom } \\
\text { atmosphere }\end{array}$ & $\begin{array}{l}\text { Noise, } \\
\text { participant, } \\
\text { chaos }\end{array}$ \\
\hline \multirow[t]{4}{*}{$\begin{array}{l}\text { Student } \\
\text { activities }\end{array}$} & $\begin{array}{l}\text { Negative } \\
\text { behaviors }\end{array}$ & $\begin{array}{l}\text { Irrelevant } \\
\text { conversations }\end{array}$ \\
\hline & \multirow{3}{*}{$\begin{array}{l}\text { Positive } \\
\text { behaviors }\end{array}$} & Presentation \\
\hline & & $\begin{array}{l}\text { Answering } \\
\text { the teacher's } \\
\text { questions }\end{array}$ \\
\hline & & $\begin{array}{l}\text { Asking relevant } \\
\text { questions }\end{array}$ \\
\hline $\begin{array}{l}\text { Cognitive } \\
\text { structure of } \\
\text { the lesson }\end{array}$ & & Concepts \\
\hline
\end{tabular}

The codes were defined based on Helmke (2009), Lipowsky (2009), and Kiel (2010), and were extended with the studies performed by Neuhaus (2007) and Wüsten et al. (2008). Both the studies of Gall (1970) and Einsiedler and Hardy (2010) were referred to in structuring questions and in the cognitive structuring of teaching. The basic criteria in the code system were to distinguish between student and teacher activities as the elements constituting the lesson. Teacher activities were structured on the basis of domain-specific teaching quality criteria, including classroom management and instilling field concepts within the general framework of general teaching quality. Apart from these, the cognitive structuring of the lesson involved the transfer of knowledge related to the topics presented in each lesson unit. Student activities are defined as the conversations related to the topics in the lesson process or as being irrelevant to them. After defining the codes and setting coding rules, the related examples were created for coding. Two experts, one of whom was employed in the field of educational administration and the other in the field of educational measurement and evaluation, were consulted for their opinions with regard to the compatibility of the table. After codings were done according to those rules, the codes were placed in upper codes and categories using an inductive method. The coding was done using MAXqda X2.

Quantitative Analysis: At this stage, a cluster analysis was performed. A cluster analysis is a statistical method with multiple variables aiming to collect individuals or objects in similar groups based on several of their characteristics (Jürgen \& Laatz, 2007; Uçar, 2005). In performing the cluster analysis, (i) firstly, the codes determined as the criteria for teaching quality were used as the comparison variables for forming the groups. (ii) The codings for these codes were then transformed into numerical data. (iii) The correlation coefficients between the codes were calculated. (iv) The presentation activity ( $r=.991, p=.00, n=21$ ) with a correlation coefficient of .90 and above, and the variables of asking questions $(r=.90, p=.00, n=21)$ and feedback $(r=$ $.92, p=.00, n=21)$ were removed from the analysis. (v) The ANOVA results were obtained for 5 clusters using the $\mathrm{k}$-means method in reducing the number of remaining variables. According to these results, the insignificant variables were removed from the analysis while forming the groups (see Table 4). ( $v i$ ) A hierarchical clustering analysis was done using the centroid linkage method. (vii) The groups formed were again tested using the k-means method (Mooi \& Sarstedt, 2011). After the concepts' numbers were transformed into $\mathrm{z}$-scores for the cognitive structuring between groups formed through the cluster analysis, they were compared. They were also evaluated qualitatively. The SPSS 19 was used to perform these analyses.

\section{The Quality Criteria of the Research}

The validity and reliability of the research were supported by various applications in addition to the research design, method, and fit of the sample selection. The applications mentioned are the collection of research data by independent observers, preparing the codes system on the basis of the literature 
and their evaluation by two different experts, and computing the inter-rater reliability for observational data between the researcher making the codings according to the coding key and another coder (Kappa value: .656, $t=26.960, p=.00$; Dawson-Saunders \& Trapp, 1994 as cited in Boyacıŏlu \& Güneri, 2006). Moreover, it was important that the analyses be varied in this research and that the qualitatively collected and analyzed data both be interpreted through statistical analyses and supported by qualitative findings. By forming the cases statistically the objectivity of this study increased. The researcher both assured the training and control of the observers in the data collection process and performed the analyses. Both the highness of the classroom's distance coefficients, which may be regarded as negative examples, and the group having a low level of homogeneity were compatible with the dynamic structure of the teaching environments and the teaching process' dependence on a number of variables, including teachers, students, and the properties of the topic presented.

\section{Findings}

\section{Grouping the Observed Classrooms on the Basis of Teaching Quality}

Decisions as to which codes determined for the grouping of the classrooms observed were significant in cluster analysis were made through $\mathrm{k}$-means method ANOVA results. In order to decide on the number of clusters at this stage, the dendrogram was examined through a hierarchical cluster analysis. In samples suggested by Uzgören and Keçek (2005), the square root of half of the number of samples was taken, and it was decided that the number of clusters would be three. The ANOVA results for the analysis are shown in Table 4.

According to Table 4, the variables of interdisciplinary teaching $(F(2,18)=10.778, p=$ $.001)$, atmosphere encouraging learning $(F(2,18)$ $=7.349, p=.005)$, structuring the teaching hour $(F(2,18)=7.567, p=.004)$, student activities $(F(2$, 18) $=13.217, p=.000)$, answering the teacher's questions $(F(2,18)=8.164, p=.003)$, and asking relevant questions $(F(2,18)=14.506, p=.000)$ are

Table 4

The ANOVA Results for the Significance of the Variables Used in Groupings

\begin{tabular}{|c|c|c|c|c|c|}
\hline & \multicolumn{2}{|c|}{ Cluster } & \multicolumn{2}{|c|}{ Error } & \multirow[b]{2}{*}{$F$} \\
\hline & Mean Square & $d f$ & Mean Square & $d f$ & \\
\hline Characteristics of the domain specific teaching & 1266.679 & 2 & 33.623 & 18 & $37.673^{*}$ \\
\hline Oral presentation & 30.962 & 2 & 9.740 & 18 & 3.179 \\
\hline Using models & .101 & 2 & .042 & 18 & 2.429 \\
\hline Analogy & .655 & 2 & .806 & 18 & .813 \\
\hline Technological support & 4.194 & 2 & 1.158 & 18 & 3.621 \\
\hline Using the blackboard & .587 & 2 & 3.988 & 18 & .147 \\
\hline Characteristics of the interdisciplinary teaching & 294.605 & 2 & 27.335 & 18 & $10.778^{*}$ \\
\hline Atmosphere encouraging learning & 59.033 & 2 & 8.033 & 18 & $7.349^{*}$ \\
\hline Structuring the teaching hour & 48.176 & 2 & 6.367 & 18 & $7.567^{*}$ \\
\hline Learning help & 1.032 & 2 & .615 & 18 & 1.677 \\
\hline Homework & 1.994 & 2 & 2.054 & 18 & .971 \\
\hline Comprehension check & .758 & 2 & .508 & 18 & 1.492 \\
\hline Avoiding waste of time & 22.426 & 2 & 9.561 & 18 & 2.346 \\
\hline Classroom atmosphere & 4.557 & 2 & 11.557 & 18 & .394 \\
\hline Preparing the teaching environment & .248 & 2 & .914 & 18 & .271 \\
\hline Complexity & 1.223 & 2 & 5.409 & 18 & .226 \\
\hline Instructive environment & .140 & 2 & 1.387 & 18 & .101 \\
\hline Participant & 2.634 & 2 & .776 & 18 & 3.394 \\
\hline Silent & .651 & 2 & 1.473 & 18 & .442 \\
\hline Sincere & .319 & 2 & .351 & 18 & .910 \\
\hline Student activities & 354.937 & 2 & 26.854 & 18 & $13.217^{*}$ \\
\hline Answering teacher's questions & 105.890 & 2 & 12.970 & 18 & $8.164^{*}$ \\
\hline Asking relevant questions & 44.990 & 2 & 3.102 & 18 & $14.506^{*}$ \\
\hline Presenting the topic & 18.121 & 2 & 8.098 & 18 & 2.238 \\
\hline Irrelevant conversations & 6.490 & 2 & 2.824 & 18 & 2.298 \\
\hline
\end{tabular}

${ }^{*} p<.05$. 


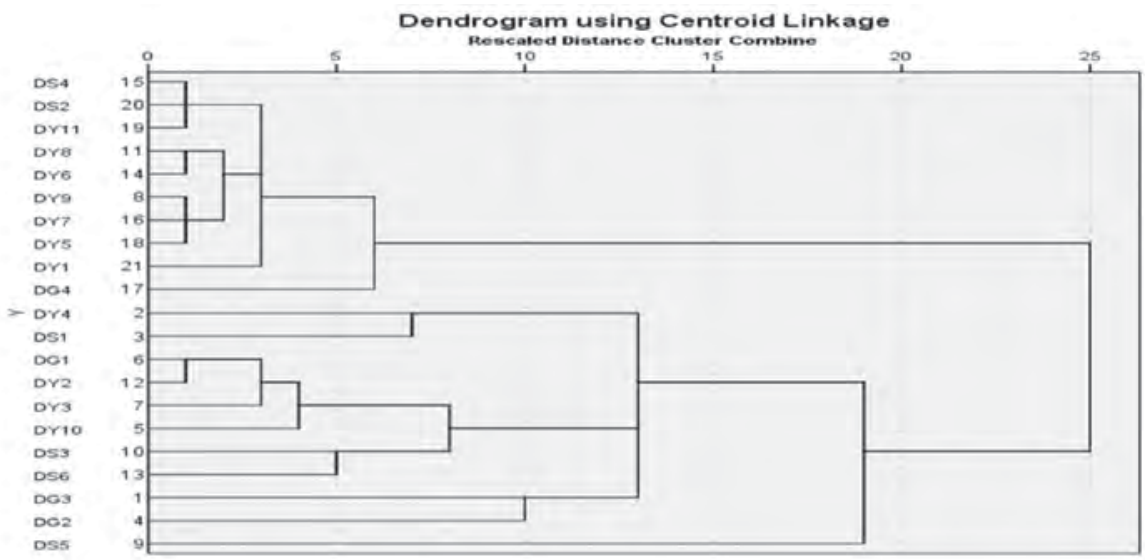

Figure 1: Dendrogram using hierarchical cluster analysis centroid linkage method.

statistically significant in forming the groups. The Dendrogram obtained as a result of the cluster analysis performed with these variables is shown in Figure 1. An examination of the Dendrogram makes it clear that the observations are divided into many sub-groups under two umbrella groups. The distance combination results are shown in Table 5. On examining the table along with the Dendrogram shown in Figure 1, it is found that the distances between observations appointed to the clusters increase after passing into different groups.

Accordingly, the distance between 1(DG 3) and 8(DY9) is the biggest. In line with this, these two observations were grouped into two different blocks. 2(DY4) and 9(DS5), along with 1(DG 3), form the borders of this cluster. It is understood that the number of groups to be formed following the analysis can be between 2 and 5 .

\begin{tabular}{|c|c|c|c|c|c|c|}
\hline \multicolumn{7}{|c|}{$\begin{array}{l}\text { Table } 5 \\
\text { Agglomeration Schedule }\end{array}$} \\
\hline \multirow[b]{2}{*}{ Stage } & \multicolumn{2}{|c|}{ Cluster Combined } & \multirow[b]{2}{*}{ Coefficients } & \multicolumn{2}{|c|}{ Stage Cluster First Appears } & \multirow[b]{2}{*}{ Next Stage } \\
\hline & Cluster 1 & Cluster 2 & & Cluster 1 & Cluster 2 & \\
\hline 1 & 15 & 20 & .000 & 0 & 0 & 5 \\
\hline 2 & 11 & 14 & .000 & 0 & 0 & 7 \\
\hline 3 & 8 & 16 & .005 & 0 & 0 & 4 \\
\hline 4 & 8 & 18 & .005 & 3 & 0 & 7 \\
\hline 5 & 15 & 19 & .005 & 1 & 0 & 8 \\
\hline 6 & 6 & 12 & .010 & 0 & 0 & 10 \\
\hline 7 & 8 & 11 & .013 & 4 & 2 & 8 \\
\hline 8 & 8 & 15 & .024 & 7 & 5 & 9 \\
\hline 9 & 8 & 21 & .022 & 8 & 0 & 13 \\
\hline 10 & 6 & 7 & .030 & 6 & 0 & 11 \\
\hline 11 & 5 & 6 & .037 & 0 & 10 & 15 \\
\hline 12 & 10 & 13 & .045 & 0 & 0 & 15 \\
\hline 13 & 8 & 17 & .056 & 9 & 0 & 20 \\
\hline 14 & 2 & 3 & .068 & 0 & 0 & 18 \\
\hline 15 & 5 & 10 & .074 & 11 & 12 & 17 \\
\hline 16 & 1 & 4 & .094 & 0 & 0 & 17 \\
\hline 17 & 1 & 5 & .126 & 16 & 15 & 18 \\
\hline 18 & 1 & 2 & .131 & 17 & 14 & 19 \\
\hline 19 & 1 & 9 & .185 & 18 & 0 & 20 \\
\hline 20 & 1 & 8 & .255 & 19 & 13 & 0 \\
\hline
\end{tabular}




\begin{tabular}{|c|c|c|c|c|c|c|c|}
\hline \multicolumn{5}{|c|}{ Cluster memberships formed in Centroid Linkage Method } & \multicolumn{3}{|c|}{ Cluster memberships formed in K-Means Method } \\
\hline Case & 5 Cluster & 4 Cluster & 3 Cluster & 2 Cluster & Case & Clusters & Distance \\
\hline 1:DG3 & 1 & 1 & 1 & 1 & DY 10 & 1 & 7.767 \\
\hline 4:DG2 & 1 & 1 & 1 & 1 & DG1 & 1 & 7.303 \\
\hline 2:DY4 & 2 & 2 & 1 & 1 & DY3 & 1 & 8.544 \\
\hline 3:DS1 & 2 & 2 & 1 & 1 & DS3 & 1 & 10.708 \\
\hline 5:DY10 & 3 & 1 & 1 & 1 & DY2 & 1 & 8.583 \\
\hline 6:DG1 & 3 & 1 & 1 & 1 & DS6 & 1 & 11.358 \\
\hline 7:DY3 & 3 & 1 & 1 & 1 & DY4 & 2 & 6.928 \\
\hline 10:DS3 & 3 & 1 & 1 & 1 & DS1 & 2 & 6.928 \\
\hline 12:DY2 & 3 & 1 & 1 & 1 & DY9 & 3 & 3.403 \\
\hline 13:DS6 & 3 & 1 & 1 & 1 & DY8 & 3 & 7.974 \\
\hline 8:DY9 & 4 & 3 & 2 & 2 & DY6 & 3 & 6.692 \\
\hline 11:DY8 & 4 & 3 & 2 & 2 & DS4 & 3 & 3.997 \\
\hline 14:DY6 & 4 & 3 & 2 & 2 & DY7 & 3 & 3.922 \\
\hline $15: D S 4$ & 4 & 3 & 2 & 2 & DG4 & 3 & 10.401 \\
\hline 16:DY7 & 4 & 3 & 2 & 2 & DY5 & 3 & 3.519 \\
\hline 17:DG4 & 4 & 3 & 2 & 2 & DY11 & 3 & 5.383 \\
\hline 18:DY5 & 4 & 3 & 2 & 2 & DS2 & 3 & 5.233 \\
\hline 19:DY11 & 4 & 3 & 2 & 2 & DY1 & 3 & 7.873 \\
\hline 20:DS2 & 4 & 3 & 2 & 2 & DG3 & 4 & 8.170 \\
\hline 21:DY1 & 4 & 3 & 2 & 2 & DG2 & 4 & 8.170 \\
\hline 9:DS5 & 5 & 4 & 3 & 1 & DS5 & 5 & .000 \\
\hline
\end{tabular}

It is understood that when the number of groups is 5, the likelihood of deriving homogeneous groups will also be high. Accordingly, cluster memberships were formed using two different methods, shown in Table 6.

According to the Table, while the numbers of clusters are different in the 5-cluster analysis performed using the centroid method and in the analysis performed using the k-means method, similar observations were grouped together. The difference stems from the rationale of the methods in forming groups. What is important here is the inclusion of both cases in the same cluster. The fact that the two cases come together in clusters in both methods makes the analyses stronger. In the next part of the study, the cluster memberships of the groups are analyzed with the cluster membership numbers obtained through the k-means method. Accordingly, the second group contains 1 case (or 1 classroom observed), the third group contains 10 cases, the fourth group contains 2 cases, and the fifth group contains 1 case. Table 7 shows which properties of the groups are similar and different based on the comparison variables considered as codes for teaching quality criteria.

The final cluster centers show the distances between cases in the final according to each variable. The results represent the averages for the clusters according to the variables while also showing the clusters' profiles. An examination of Table 7 demonstrates that cluster 3 has the lowest averages in all variables and that it is distinctively

Table 7

Final Cluster Centers in terms of Variables

\begin{tabular}{lccccc}
\hline & \multicolumn{5}{c}{ Clusters } \\
\cline { 2 - 6 } & 1 & 2 & 3 & 4 & 5 \\
\hline Domain specific teaching & 19.00 & 35.50 & 5.50 & 28.00 & 43.00 \\
Interdisciplinary teaching & 13.00 & 6.50 & 5.80 & 26.00 & 19.00 \\
Atmosphere encouraging learning & 3.00 & .50 & .80 & 12.00 & 5.00 \\
Structuring the teaching hour & 7.00 & 3.00 & 3.20 & 9.50 & 7.00 \\
Student activities & 16.67 & 12.50 & 3.10 & 8.00 & 21.00 \\
Answering the teacher's questions & 7.67 & 5.00 & 1.20 & 5.50 & 15.00 \\
Asking relevant questions & 2.67 & 7.00 & .40 & .50 & 5.00 \\
\hline
\end{tabular}


different from the other clusters. While cluster 2 has the second highest average in terms of domain specific teaching, it is similar to cluster 3 in its interdisciplinary teaching average, in providing an atmosphere encouraging learning, and in structuring the teaching hour. It furthermore has the lowest average. Yet, the student activities in this group differ from cluster 3, displaying a student profile which both asks questions and which answers the teacher's questions. Cluster 4 , in contrast to cluster 2, has higher averages in interdisciplinary teaching, in providing an atmosphere encouraging learning, and in structuring the teaching hour. In relation to student activities, the averages for asking relevant questions are quite low. Cluster 4 differs from clusters 1 and 5 in student activities and in its averages for asking relevant questions. Cluster 5 has the highest averages in domain specific teaching, student activities, and answering the teacher's questions. While cluster 1 has lower averages in domain-specific teaching, it is similar to cluster 5 in terms of the other variables.

\section{An Evaluation of the Clusters in Terms of Cognitive Structuring}

For all of the study group, the arithmetic average for the number of concepts, which was the variable for cognitive structuring, was calculated as 21.52, the standard deviation as 18.77 , the smallest value as 2 , and the biggest value as 76 . Figure 2 shows the averages for the groups in terms of the number of concepts communicated.

Accordingly, while clusters 1 and 5 are very close to one another, clusters 2 and 4 are close to one another. Clusters 1,3, and 5 have values below the average for the whole study group whereas clusters 2 and 4 have averages above the general average. Thus, it may be said that there are differences between groups in terms of the number of concepts communicated in the lesson process.

\section{Qualitative Analysis Findings}

In this part, the observational findings on which the statistical analyses are based are evaluated qualitatively, and the qualitative quotations related to group profiles are described in depth. For this, all the classrooms observed were sequenced based on the cluster analysis, and the codes distribution matrix was derived, as is seen in Figure 3. The codes and the codings for the codes belonging to the classrooms observed are shown in the codes distribution matrix as squares. The size of the squares shows the number of codings. The form of the matrix that had been transformed into numerical data formed the basis for the cluster analysis, and it was used for statistical calculations.

It is obvious from the finding that the statistically insignificant variables were coded in the majority of the observations or that they were coded in 2 or 3 observations by using analogies, for example. Because the cluster analysis grouped the observations by determining the distances according to the averages of the variables, they were not considered as significant variables.

The classrooms observed in the two cases included in cluster 4 are in the same school, in the same class (11E), and have the same teacher, according to Table 2. It is seen that the topic on the Digestive System was studied again in the lesson. This is the group with the highest number of concepts communicated (see Figure 2). According to Figure 3 , the techniques of oral presentation and asking questions were heavily used in domain-specific teaching whereas doing activities promoting an atmosphere encouraging learning, avoiding the waste of time, and structuring the teaching hour were used as variables rating general teaching quality. The questions that the teacher asked students or the questions that the teacher answered, feedback given, and learning aids were remarkable in the cognitive structuring process.

"L: we are going to complete the missing part. Say it. S: stomach is the organ for digestion. The place

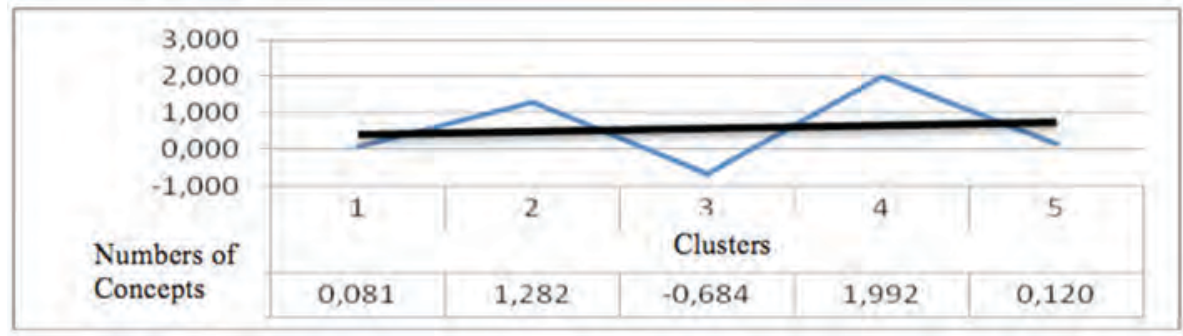

Figure 2: A comparison of the clusters' numbers of concepts communicated according to $z$-scores. 


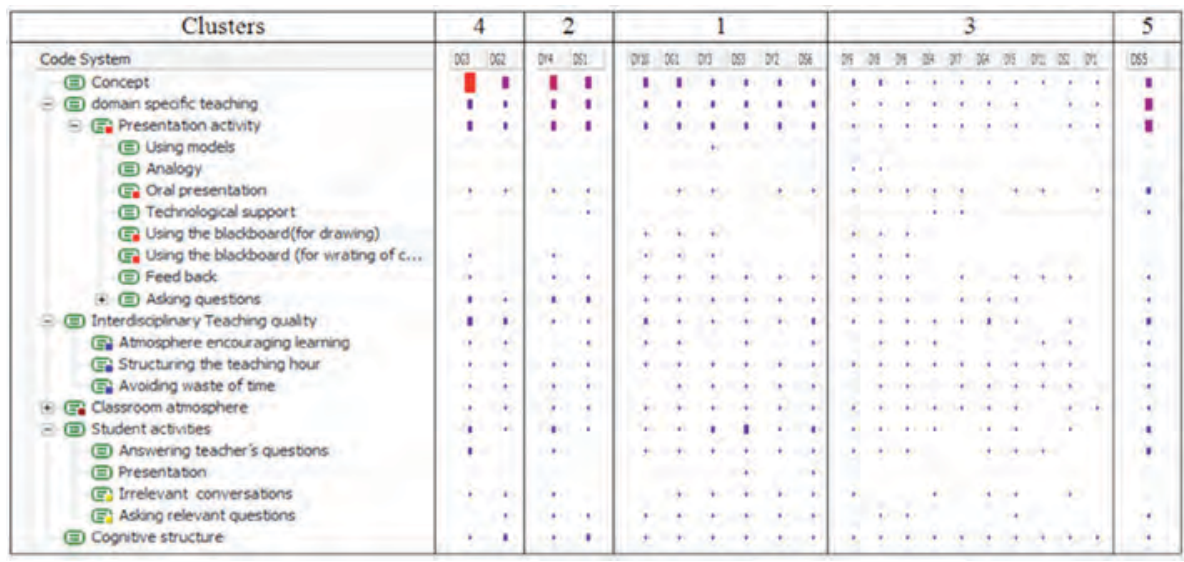

Figure 3: Coding distribution matrix for the cases observed.

where the stomach begins with oesophagus is called the pylorus. It is covered with three layers of membranes coming from outside. L: Think again, at the outside? (The student could not continue here). You don't need to memorize it. It is covered with mucus. Isn't it? How is mucus produced? From goblet cells. So what is in it? S: Epithelium tissue." (G4, DG3, 34-37)

Codings related to giving homework were observed in cluster 4 .

"Study and get ready for the Circulatory System in humans for Monday." (G4, DG3, 104-104)

"L: you have homework for next week. Study the duties of gall of cholesterol..." (G4, DG2, 109-110)

It was found that assignments were not prestructured according to homework codes, that homework checks were done at the beginning of the classes, and that the students were made to feel that doing the homework was important. The code for avoiding the waste of time and spoilage was frequently seen in this cluster.

"Yes. That's enough. Stop talking." (G4, DG3, 1010)

"L: why are you still talking with your friend, Seçil. We have already wasted time. What's the problem?” (G4, DG4, 36-36)

"L: Ümmü! Why isn't your notebook open? Hurry up! Open it." (G2, DG3, 23-25)

On examining those codings, it was found that the teacher had strict control over the classroom. Besides warning the students without pronouncing the names, the teacher also responded to small groups or to individuals by saying their names. In some cases, the teacher was found to give more strict responses, but did so in order to avoid conflicts. It was also observed that the teacher continually reminded students of the sub-heading that they were studying and tried to encourage students to learn in order to structure the teaching hour. The relevant quotations are:

"L: That's all for the stomach. Now we come to the duodenum." (G2, DG3, 59-59)

“... now the small intestine." (G2, DG3, 88-89)

An examination of the data in relation to cluster 2 in Table 2 makes it clear that they come from different types of schools, have different teachers, and are at different grade levels (DY4, $9^{\text {th }}$ graders, DS1 $11^{\text {th }}$ graders). A lesson on carbohydrates was taught in the classroom coded as DY4 whereas one on the organs helping digestion was taught in the classroom coded as DS1. An above average number of codes was also communicated in this group. Presentations were done with the help of a projector in the classroom coded as DS1. It was found in relation to cognitive structuring that the concepts were communicated by the teacher to the learners using differing techniques.

"L: How do you understand that a substance contains chitin and starch?" (Classroom silent) (G2, DY4, 56-62)

"L: what type of an animal could it be?" (The teacher showing the picture of the digestive system of a herbivorous mammal turned to the students and asked them.) (G2, DS1, 50-53)

The question and answer technique was used in cluster 2. Yet, in contrast to cluster 4, the questions were related to daily life, and the types of questions ensuring and deepening comprehension were employed. To exemplify this: 
"L: (Showing a reaction in the slides, the teacher asked) where do you think this reaction is happening?" (G2, DS1, 97-98)

"L: what are the polysaccharides in your life?" (G2, DY4, 44-45)

In relation to student activities, while there were no differences between clusters 2 and 4 in answering the teacher's questions, it was observed that the students asked the teacher questions in cluster 2, as is clear from Table 7 . The quotation supporting this is as follows:

"S: But when I drink milk, it is not sugary." (DY4, 33-33)

“S: Does honey contain sugar?” (DY4, 34-34)

"S: which one releases albumin? I think it hinders the formation of oedema in the body in cold places." (G2, DS1, 83-84)

Cluster 2 was different from cluster 4 in interdisciplinary teaching, in providing an atmosphere encouraging learning, and in the codes for structuring the teaching process. Students' participation in the lesson reduced the negativities in terms of classroom management. Although a smaller number of concepts was communicated, they were presented in deeper relations. Cluster 5 involved only one observation: the observation coded as DS5. It was performed in an Anatolian High School, grade ten in which students were studying Ecological Units. It was taught by a female teacher with 14 years of experience. The presentation was done with a projector and the domain specific teaching here had the highest average of all groups in terms of students answering the teacher's questions (see Table 7). On examining Figure 3, it was found that presenting the topic, asking questions, and giving feedback were coded more than the other codes related to domain-specific teaching. The number of concepts communicated was smaller in this cluster than the number communicated in clusters 2 and 4. An example of cognitive structuring in which the concepts were communicated is presented as follows:

"L: Today we are going to have a look at the important concepts in ecology! Yes, let's start with what ecology is. Who can define it? (The teacher permitted a student raising his/her hand to speak. The teacher was standing in front of the class)

S: It is the mutual relations between living and non-living things in nature (another student interrupted).

The other student: Ma'am! Ecology is a science which studies the mutual relations between living and non-living things in nature.
L: Yes, these are all correct. Alright, let's make a generalization then. Ecology is one of the subbranches of biology, which studies the mutual relations between living and non-living things and their relations with the environment... (The class is listening to the teacher standing in front of them.).

L: Okay then. What is the terminological equivalent of the environment of living specific to a species of living things? (Looking at the class.)

S: Habitat. Yes, we call it habitat (The class listening silently)...

$\mathrm{L}$ : So what is in the heart of the word ecosystem? Let's see (The teacher reads the definition turning to the presentation)... In your opinion, how can we extend this definition? What's your opinion Zeynep? (Looking at the student.)

S: Do you mean the other components in the ecosystem, maam? Such as producer and consumers?" (G5, DS5, 30-47)

As is clear from the quotation, concepts were presented by having the students make comments and with feedback and oral explanations. The observer notes showed that the class was listening to the teacher. The teacher called the students by their names and answered their questions. The teacher's questions were of the type that encouraged learners to think cognitively, that demanded examples, that made sure that they distinguished between concepts, and were deepening questions. Examples of this include the following:

"How do you think this definition can be extended?” (G5, DS5, 44-45)

"To be more specific, are the oak forests in the Black Sea Region ecosystems?" (G5, DS5, 67-67)

"L: Who can give an example?" (G5, DS5, 67-67)

Cluster 1 involved six observations of different schools and grade levels. The topics were The Digestive System, Respiration, and Ecology. The teachers were female and had 12 to 13 years of experience. According to Table 7, student activities in cluster 1 were similar to those in clusters 2, 4, and 5 in terms of the averages for interdisciplinary teaching quality and for domain-specific teaching quality. This case shows, as is clear from Figure 3, that the codes for domain-specific teaching, for asking questions, and for feedback are more in cluster 1. According to Figure 2, cluster 1 is closer to the average in terms of the number of concepts communicated and has higher values than cluster 3 . On examining the quotations related to this group, 
it was found that the teacher made the learners write down the topic, that she presented the topic by drawing on the board, and that she intervened during chaotic situations in the classroom.

"The teacher drew the Krebs Cycle on the board. She asked the students to copy it down into their notebook. She used a variety of chalk colors in drawing it." (G1, DY10, 75-75)

"The teacher is teaching the digestive system. I couldn't catch what she did in the meanwhile. There is still noise sound in the classroom." (G1, DG1, 41-43)

While cluster 1 was trying to explain the topic in terms of cognitive structuring, the flow of concepts kept going through measures while avoiding wasting time

"L: Now let's talk about arthropods. Their intestine is divided into three: the front, back, and middle. What is at the front?

S: the mouth, oesophagus, gizzard (a girl raised her hand as she answers the question)

(In the meantime, the teacher continues to describe the digestive system, I couldn't catch what happened, there is still noise in the classroom.)

L: the tip of the mouth in flies is absorbent, piercing, and tractive. Any questions so far?" (G1, DG1, 34-39)

"L: Yes! (Shouting and coming to the front of the board).where are we now? I don't want you to write down because it's in the book. Birds don't have teeth in their mouth or beak. There is no mechanical digestion in the mouth. So, what happens then?" (G1, DG1, 51-53)

Cluster 3 had the highest number of observations. It contained different schools, classrooms, and teachers. DG4 and DS4 were the groups of teachers who also had taken part in the other clusters during their observations. The observations coded as DY were the lesson processes of two teachers, one of whom was female and the other of whom was male. On examining the codes in cluster 3 , we noticed time being wasted due to an inappropriate classroom atmosphere, a video watched by the class related to the topic, the presentation of advanced level concepts, and unclear oral presentations. Below is an example for this:

"(Noise caused time to be wasted in the class. The teacher did not manage to silence the class no matter how much she tried by threatening with marks.)" (G3, DY8, 32-33). "(The teacher moved the teacher's chair to the back of the classroom and the student started to play the video and sat down. The title of the first video was 'What is ecology?' All the students began to watch it carefully.)" (DS4, 14-16)

"L: Today, you will do the test that I have prepared for you.” (G3, DS2, 13-13)

On examining the final cluster centers shown in Table 7, it was found that the low coding averages for all variables revealed that the lesson was monotonous. It was observed in the group that teaching was conducted using question and answer techniques heavily. Yet, the questions were asked and answered by the teacher. There were no teacher feedbacks in this cluster.

\section{Discussion}

The findings obtained from the study group are discussed in this part within the framework of the literature. Determining the statistically significant variables (Table 4 ) in order to use the qualitative analysis results in cluster analysis shows that interdisciplinary teaching quality and student activities emerge as important factors in the lesson process. That this analysis is compatible with the qualitative analysis (Figure 3 ) is understood with the variables observed in the classrooms. The findings concerning cluster memberships (Table 6, Figure 1) and concerning the descriptive properties in those clusters (Table 4) show that the implementation of teaching quality criteria depend on teachers' characteristics and that it is also influenced by the classroom structure and by students' properties. It is also observed here that lesson processes differ both when the same teacher teaches in a different classroom and when she teaches a different topic in the same classroom (see Table 4; the classrooms with the DS code). This is also supported by the finding of cluster distances. Cluster distances with a distribution of large intervals signal the low similarity between groups. It is noticed in the literature (Doyle, 1977; Helmke, 2003; Rixius \& Neuhaus, 2010) on teaching quality that the theoretically set criteria are more in number. The paradigm changes experienced in researching those criteria are associated with the variables focused on. The variables may be stated briefly as teachers' professional efficacies, teachers' leadership or classroom management skills, the necessities of domain-specific teaching, and students' interests or eagerness. These variables 
emerge in the dynamic environment of the classroom as a whole and in interaction with each other. The diversity of criteria used to determine teaching quality in the classrooms observed in this study and the difference in the way the research was performed is compatible with this theoretical framework. We see that the cluster profiles (Table 7) are based on the differences in averages for student activities as well as for interdisciplinary and domain-specific teaching quality criteria. It is clear that domain-specific teaching, interdisciplinary teaching, and student activities influence each other. Cluster 4, which has the biggest number of concepts communicated, has the highest average in terms of interdisciplinary teaching quality criteria but also has the lowest average in terms of students' asking questions. The qualitative analysis results for this group exhibits that the teacher displays very strict classroom management. Here, the teacher's effective interventions preventing negative effects to the teaching process come into prominence. Classroom management is described as those teacher activities related to providing conditions for the most effective teaching. Kouin (1976 as cited in Helmke, 2010) points out that the disturbances occurring the most frequently in the classrooms are noisyor whispering, noise, talking aloud, laughing, and digressing from the topic; and the author then adds to the list: being late for classes, failing to do homework or bring the necessary course material, and leaving one's seat without permission. Three main measures are recommended to deal with such behaviors: Being open, being strict, and being harsh. Cluster 4 upholds a strict classroom management tendency and raised domain-specific teaching activities. Cluster 2, on the other handdespite being similar to that group in other aspectshad an atmosphere encouraging learning in which students asked questions. The number of concepts was smaller in cluster 2 than in cluster 4 , but was bigger than in the other clusters. This finding demonstrates that the classroom atmosphere and students' characteristics are influential in teachers' conception of classroom management and that an atmosphere encouraging learning raises students' participation in the class. In parallel to this finding, it is stated in the literature that a good teaching atmosphere is among the key conditions for effective learning. The fact that these clusters, which were formed on the basis of observed interdisciplinary teaching quality, have different averages in terms of the number of concepts communicated gives importance to the applications in variables of domain-specific and interdisciplinary teaching quality. Despite having properties similar to clusters 2 and 4 , the number of concepts communicated in cluster 5 is smaller than in those clusters. On examining the techniques used in cluster 5 in the cognitive structuring process and in interdisciplinary teaching, it was found that the concepts were highlighted and that the average rate of students' comments was high. The teacher's questions and feedback were different in that classroom. It is pointed out that feedback focusing only on whether students' knowledge is correct or incorrect do not have an effect on learning achievement in general. It is instead recommended that feedback not only be evaluative and consistent with learners' prior knowledge, but also with the complexity of the task (Klugger \& DeNisi, 1996). This points to students' characteristics, and is supportive of the findings obtained in this study. The fact that the questions asked in this study were mostly at the level of knowledge caused us to think that the concepts had not been taught in depth. Learning the concepts in depth through questions asked depends on deepening questions. Asking deepening questions, on the other hand, are connected with feedback and positive student activities. Using deepening questions and evaluative feedback in cluster 5 caused a reduction in the number of concepts presented. Compared to cluster 3 , whose number of concepts was lower, we conclude that the lower number of concepts presented in this group was a result of negative classroom atmosphere, ineffective classroom management, and the concepts discussed not being understood. A case clearly emerging in clusters 3 and 1, which was also encountered in other groups, was the lack of variation in methods. The techniques of asking questions, feedback, and oral presentation were dominantly used in the lesson. In clusters 1 and 3 however, video watching and having the learners take notes were heavily used. This case restricts the variety in methods and causes concepts to be over or under presented, rendering the issue incomprehensible. It was observed that two, three, or four concepts were presented in those groups in such topics as Cells, The Respiration System, and Aerobic Respiration. Temelli and Kurt (2011) report that biology teachers employ direct types of instruction, question and answer techniques, and demonstrations respectively in biology teaching and that although they think the lab method is effective in increasing achievement levels, they use it at lower rates. This quantitative research finding is compatible with the qualitative findings obtained in the current study. In the whole of the data collected 
in the research from the study group, it was found that the process of teaching performed in ways compatible with biology was very little and that the use of models was very limited. Concept presentation was done according to classroom management and student characteristics in the teaching processes where materials were used were not available. This enables teachers with stricter classroom management bias to present more concepts. Wüsten et al. (2010), in their comprehensive research concerning the determination of biology teaching quality criteria, consider the competent use of mental or real models, the use of real materials or living things in classes, and the use of study methods specific to biology to be properties specific to biology teaching. Atıc1 and Bora (2004), however, suggest that it is possible for a biology course to attain its goals by conducting it theoretically and experimentally in parallel. Therefore, it is emphasized that making use of the structural and functional models, using plant and animal models in particular, and using organ and skeleton models will raise students' interest in their biology course and will help to ensure the subject be remembered for a long time.

To conclude, this study found that the criteria for high quality biology teaching was partly achieved in terms of concept presentation, scientific accuracy of the point being presented, its compatibility in terms of content and intelligibility, and the use of tasks requiring cognitive performance. On the other hand, criteria were insufficient in terms of using real objects and living things, making the levels of biological system intelligible, and using models and study methods compatible with science studies. It was also found that interdisciplinary teaching quality criteria were influential in biology teaching, that it affected the formation of cognitive structure, that question asking and feedback in particular were prominent in concept presentation and structuring, and that those variables were used by teachers relatively but that the desired quality criteria were not achieved in terms of gaining biology-specific teaching methods and skills related to the scientific process.

It has become evident through direct observation of biology teaching processes or through the video analyses of the process that we need to increase the scientific data in this field. Researching the process of biology teaching from the perspective of each quality criterion and for the teaching of each topic will direct the research improvement activities concerning teacher training and professional development beside the description of the situation in terms of the criteria.

\section{References}

Altunoğlu, D., \& Atav, E. (2005). Daha etkili bir biyoloji öğretimi için öğretmen beklentileri. Hacettepe Üniversitesi Eğitim Fakültesi Dergisi, 28, 19-28.

Atıc1, T., \& Bora, N. (2004). Orta öğretim kurumlarında biyoloji eğitiminde kullanılan öğretim metotlarının ders ögretmenleri açısından değerlendirilmesi ve öneriler. Afyon Kocatepe Üniversitesi Sosyal Bilimler Enstitüsü Dergisi, 6(2), 51-64.

Aydın, S., \& Boz, Y. (2012). Fen öğretmen eğitiminde pedagojik alan bilgisi araștırmalarının derlenmesi: Türkiye örneği. Kuram ve Uygulamada Eğitim Bilimleri, 12, 479-505.

Bellack, A. (1972). Methoden zur beobachtung des unterrichtsverhaltens von lehrern und schülern. In C. Wulf (Ed.), Evaluation: Beschreibung und bewertung von unterricht, curricula und schulversuchen (pp. 211-238). München : R. Piper \& Co. Verlag.

Berck, K.-H. (2005). Biologiedidaktik - Grundlagen und methoden. Wiebelsheim: Quelle \& Meyer.

Boyacıoğlu, H., \& Güneri, P. (2006). Sağlık araștırmalarında kullanılan temel istatistik yöntemler. Hacettepe Dişhekimliği Fakültesi Dergisi, 30(3), 33-39.

Clausen, M., Reusser, K., \& Klieme, E. (2003). Unterrichtsqualität auf der basis hoch-inferenter unterrichtsbeurteilungen. Unterrichtswissenschaft, 31, 122-141.

Çakmak, Z., Uzgören, N., \& Keçek, G. (2005). Kümeleme analizi teknikleri ile illerin kültürel yapılarına göre sinıflandırılması ve değişimlerinin incelenmesi. Dumlupınar Üniversitesi Sosyal Bilimler Dergisi, 12, 15-36. Retrieved from http://sbe.dumlupinar.edu.tr/12/15-36.pdf

Çimer, A. (2004). A study of Turkish biology teachers' and students' views of effective teaching for improving teaching in schools and teacher education (Doctoral dissertation, The University of Nottingham, U.K.). Retrieved from http:// www.tused.org/thesissummary/default.asp?islem=detaylar\&id $=130$

Ditton, H. (2002). Unterrichtsqualität - Konzeptionen, methodische überlegungen und perspektiven. Unterrichtswissenschaft, 30, 197-212.

Doğan, O. (2006). 6. sinıf ilköğretim matematik derslerinin yapısı üzerine bir çalıșma (Doctoral dissertation, METU, Ankara, Turkey). Retrieved from https://tez.yok.gov.tr/ UlusalTezMerkezi/

Doyle W. (1977). Paradigms for research on teacher effectiveness. Review of Research in Education, 5, 163-198.

Einsiedler, W., \& Hardy, H. (2010). Kognitive strukturierung im unterricht: Einführung und begriffsklaerungen. Unterrichtswissenschaft, 38, 194-209.

Einsiedler, W. (2002). Das konzept der unterrichtsqualität. Unterrichtswissenschaft, 30, 194-196. 
Eschenhagen, D., Kattmann, U., \& Rodi, D. (2007). Fachdidaktik biologie. Köln: Aulis.

Fischer, H. E., Borowski, A., Kauertz, A., \& Neumann, K. (2010). Fachdidaktische unterrichtsforschung unterrichtsmodelle und die analyse von physikunterricht. Zeitschrift für Didaktik der Naturwissenschaften, 16, 59-75.

Gall, M. D. (1970). The use of questions in teaching. Review of Educational Research, 40(5), 707-721.

Gürbüz, H., \& Sülün, A. (2004). Türkiye’ de biyoloji öğretmenleri ve biyoloji öğretmen adaylarının nitelikleri. Milli Eğitim Dergisi, 161. Retrieved from http://dhgm. meb.gov.tr/yayimlar/dergiler/Milli_Egitim _Dergisi/161/ gurbuz-sulun.htm

Hasselhorn, M., \& Gold, A. (2006). Erfolgreiches lernen paedagogiesche psychologie und lehren. Stuttgart: Kohlhammer Verlag.

Helmke, A. (2002). Kommentar: Unterrichtsqualität und unterrichtsklima: Perspektiven und sackgassen. Unterrichtswissenschaft, 30, 261-277.

Helmke, A. (2003). Unterrichtsqualität: Erfassen, bewerten, verbessern. Seelze: Klett-Kallmeyer

Helmke, A. (2009). Unterrichtsqualität und lehrerprofessionalität: Diagnose, evaluation und verbesserung des unterrichts. Seelze: Klett-Kallmeyer

Helmke, A. (2010). Unterrichtsqualität. In D. Rost (Ed.), Handwörterbuch paedagogische psychologie (4th ed., pp. 886-895). Weinheim: Beltz PVU.

Hugener, I., Pauli, C., Reusser, K., Lipowsky, F., Rakoczy, K., \& Klieme, E. (2009). Teaching patterns and learning quality in Swiss and German mathematics lessons. Learning and Instruction, 19, 66-78.

Jürgen, J., \& Laatz, W. (2007) Statistische daten analyse mit SPSS für Windows (6th ed.). Berlin, Heidelberg: Springer Verlag.

Kaya, E., \& Gürbüz, H. (2002). Lise ve meslek lisesi öğrencilerinin biyoloji öğretiminin sorunlarına ilișkin görüşleri. Erzincan Eğitim Fakültesi Dergisi, 4(2), 11-21.

Kiel, E. (2010). Unterrichtsforschung. In R. Tippelt \& B. Schmidt (Eds.), Handbuch bildungsforschung (3th ed., pp. 773-791). Wiesbaden: Vs Verlag.

Killermann, W., Hiering, P., \& Starosta, B. (2009). Biologieunterricht heute: Eine moderne fachdidaktik. Donauwörth: Auer Verlag.

Kluger, A. N., \& DeNisi, A. (1996). The effects of feedback interventions on performance: Historical review, a metaanalysis and a preliminary feedback intervention theory. Psychological Bulletin, 119, 254-284.

Koç, Y., Peker, D., \& Osmanoglu, A. (2009). Supporting teacher professional development through online video case study discussions: An assemblage of preservice and inservice teachers and the case teacher. Teaching and Teacher Education, 25, 1158-1168.

Köhler, K. (2004). Welche fachgemaessen Arbeitsweisen werden im Biologieunterricht eingesetzt? In U. S. Eichmann \& W. Rupert (Eds.), Biologie didaktik: Praksishandbuch für die sekunderstufe I und II (pp. 146-158). Berlin: Cornelsen Scriptor.

Lipowsky, F. (2009). Unterricht. In E. Wild \& J. Möller (Eds.), Paedagogische psychologie (Lehrbuch) (pp. 74-98). Heidelberg: Springer Verlag.

Mayer, J. (2007). Erkenntnisgewinnung als wissenschaftliche problemlösen. In D. Krüger \& H. Vogt (Eds.), Theorien in der biologiedidaktischen forschung: Ein handbuch für lehramtsstudenten und doktoranden (pp. 176-186). Berlin: Heidelberg: Springer
Mayring, P. (2002). Einführung in die qualitative sozialforschung (5th ed.). Weinheim: Beltz Verlag.

Mooi, E., \& Sarstedt, M. (2011). A concise guide to market research the process, data, and methods using IBM SPSS statistic. Berlin-Heidelberg: Springer.

Neuhaus, B. (2007). Unterrichtsqualität als forschungsfeld für empirische biologiedidaktische studien. In D. Krüger \& H. Vogt (Eds.), Theorien in der biologiedidaktischen forschung: Ein handbuch für lehramtsstudenten und doktoranden (pp. 243-254). Berlin - Heidelberg: Springer.

O'Sullivan, M. (2006). Lesson observation and quality in primary education as contextual teaching and learning processes. International Journal of Educational Development, 26, 246-260.

Öztaş, H., \& Özay, E. (2004). Biyoloji öğretmenlerinin biyoloji öğretiminde karşılaştıkları sorunlar (Erzurum Örneği). Kastamonu Eğitim Dergisi, 12(1), 69-76.

Öztürk Akar, E. (2005). Lise biyoloji dersi öğretim programının uygulanmasında okul düzeyinde görülen farklılıklar. Eğitim Bilimleri ve Uygulama, 4(7), 51-67.

Öztürk, E., \& Demircioğlu, H. (2002). Lise biyoloji öğretim programı uygulamasında öğretmen rolü. Retrieved from http://www.fedu.metu.edu.tr/ufbmek-5/b_kitabi/PDF/ Biyoloji/bildiri/t26d.pdf

Pavlina, K., Zorica, M. B., \& Pongrac, A. (2011). Student perception of teaching quality in higher education. Procedia Social and Behavioral Sciences, 15, 2288-2292.

Rixus, J., \& Neuhaus, B. J. (2010). Die qualitaet des unterrichtsgesprächs im biologieunterricht. Erkenntnisweg Biologiedidaktik, 179-193. Retrieved from http://www. bcp.fu-berlin.de/biologie/arbeitsgruppen/didaktik/ Erkenntnisweg/2010/ Rixius_2010_2-12.pdf?1342446954

Schmelzing, S., Wüsten, S., Sandmann, A., \& Neuhaus, B. (2008). Das fachdidaktische wissen der lehrkraft als einflussfaktor für die unterrichtsqualität im biologieunterricht. Erkenntnisweg Biologiedidaktik, 7, 159-168. Retrieved from http://www.bcp.fu-berlin.de/biologie/arbeitsgruppen/ didaktik/Erkenntnisweg/2008/2008_11_Schmelzing.pdf

Shadreck, M., \& Isaac, M. (2012). Science teacher quality and effectiveness: Gweru Urban Junior Secondary School students' points of view. Asian Social Science, 8(8), 160-165.

Temelli, A., \& Kurt, M. (2011). Biyoloji öğretmenlerinin kullandıkları öğretim yöntemleri ve bu yöntemlerin öğrenci başarısına etkileri hakkındaki görüşler. E-International Journal of Educational Research, 2(2), 65-76.

Uçar, N. (2005). Kümeleme analizi. In S. Kalayc1 (Ed.), SPSS uygulamal çok değişkenli istatistik teknikler (pp. 350-369). Ankara: Asil Yayın Dağıtım.

Wadouh, J. (2007). Vernetzung und kumulatives lernen im biologie unterricht (Doctoral dissertation, Universität Duisburg-Essen, Germany). Retrieved from http:// duepublico.uni-duisburg-essen.de/servlets/DerivateServlet / Derivate-20492/Dissertation_komplett_5_bib_end.pdf

Wüsten, S., Schmelzing, S., Sandmann, A., \& Neuhaus, B. (2008). Unterrichtsqualitätsmerkmale im fach biologie. Erkenntnisweg Biologiedidaktik, 7, 145-158. Retrieved from http://www.bcp.fu-berlin.de/biologie/arbeitsgruppen/ didaktik/Erkenntnisweg/2008/2008_10_Wuesten.pdf

Wüsten, S., Schmelzing, S., Sandmann, A., \& Neuhaus, B. (2010). Sachstrukturdiagramme-Eine methode zur erfassung inhaltspezifischer merkmale der unterrichtsqualitaet im biologie unterricht. Zeitschrift für Didaktik der Naturwissenschaften, 16, 7-23.

Yıldırım, A., \& Șimșek, H. (2006). Sosyal bilimlerde nitel araştırma yöntemleri (5th ed.). Ankara: Seçkin Yayınları. 